\title{
The evolution of a submarine landform record following recent and multiple surges of Tunabreen glacier, Svalbard
}

\author{
Anne Elina Flink', Riko Noormets ${ }^{1}$, Nina Kirchner² Douglas I. Benn³, \\ Adrian Luckman ${ }^{1,5}$, Harold Lovell ${ }^{41}$
}

${ }^{1}$ Departments of Arctic Geology and Arctic Geophysics, University Centre in Svalbard, 9170 Longyearbyen, Norway

${ }^{2}$ Department of Physical Geography and Quaternary Geology and Bolin Centre for Climate Research, Stockholm University, 10691 Stockholm, Sweden

${ }^{3}$ Department of Geography and Sustainable Development, University of St Andrews, KY16

$9 A L$, St Andrews, Scotland, UK ${ }^{4}$ School of Geography, Queen Mary University of London, E14NS, London, UK

Department of Geography, College of Science, Swansea University, SA2 8PP, UK

Corresponding author: Anne Elina Flink, University Centre in Svalbard, PO Box 156, 9171 Longyearbyen, Norway, AnneF@unis.no

\section{Abstract}

This study focuses on the glacial landform record associated with recent surge events of Tunabreen - a calving tidewater glacier in Tempelfjorden, Spitsbergen. Submarine geomorphology and recent terminal fluctuations of Tunabreen's glacier front were studied using high-resolution multibeam- bathymetric data and a range of published and remotesensing sources, including topographic maps, satellite images and aerial photographs. The retreat moraines in the inner part of Tempelfjorden have been correlated with glacier terminus positions during retreat from the 2004 surge maximum. Glacier surface velocity and ice-front positions derived from high-resolution TerraSAR-X satellite data show ice movements at the glacier front during minor advances of the front in winter when calving is suppressed. This suggests that the moraines have formed annually during quiescent phase winter advances. 
Tunabreen has experienced three surges since the Little Ice Age (LIA). This is in contrast with most Svalbard surging glaciers which have long quiescent phases and have typically only undergone one or two surges during this time. The landform record in Tempelfjorden is distinguished from previously studied glacier-surge landsystems by four, well-preserved sets of landform assemblages generated by the LIA advance and three subsequent surges, all of which partly modify earlier landform records. Based on the unique landform record in Tempelfjorden, a new conceptual landsystem model for frequently surging glaciers has been put forward improving our understanding of the dynamics of the surging glaciers and, most importantly, how they can be distinguished from the climatically-controlled glaciers in the geological record.

Keywords: Submarine landforms, Tidewater glacier, Glacier surges, Multibeam-bathymetric data, Remote sensing, Svalbard.

\section{Introduction}

Glaciers are sensitive indicators of climate change, and sequences of moraines demarcate glacial retreat or readvance that can often be used as proxies for past climatic fluctuations. However, major glacier advances known as surges, can also occur in response to internal dynamical processes which are largely thought to be unrelated to climatic variations (Meier \& Post 1969; Fowler et al. 2001). Glacier surges in the High-Arctic archipelago of Svalbard are characterized by long periods of quiescence (100-150 years) punctuated by short phases of increased ice velocities, usually accompanied by terminus advance. These surge events, or active phases, typically last for 3-10 years (Dowdeswell et al. 1991; Murray et al. 2003). To avoid misinterpretation, it is important to distinguish glacial landforms formed during surges from those created by climatically-controlled advances. 
Conceptual descriptions of glacial landform records, known as landsystem models, have been developed for both, terrestrial and fjord-terminating surging glaciers (e.g. Evans \& Rea 1999, 2003; Ottesen \& Dowdeswell 2006; Ottesen et al. 2008; Benediktsson et al. 2010; Brynjólfsson et al. 2012). However, it is likely that the examples described to date encompass only part of the range of variation. There is a particular need for studies of glacial landform records that can be directly linked to observed surge events, to provide benchmarks for the interpretation of geomorphological data where the glacial history is not independently known.

In this paper, we present detailed observations of the glacial landform record of Tunabreen, a tidewater surge-type glacier in central Spitsbergen (Fig. 1). The glacier is known to have surged in c.1930, 1971 and 2003-2005. Glacier behavior during and following the 20032005 event is particularly well known (e.g. Fleming et al. 2013). Using a combination of multibeam echosounding mapping of the fjord floor, remote-sensing data, and ground-based observations of the glacier we show how the geomorphological record in Tempelfjorden expresses key glaciological processes which have been active during multiple surge cycles. 


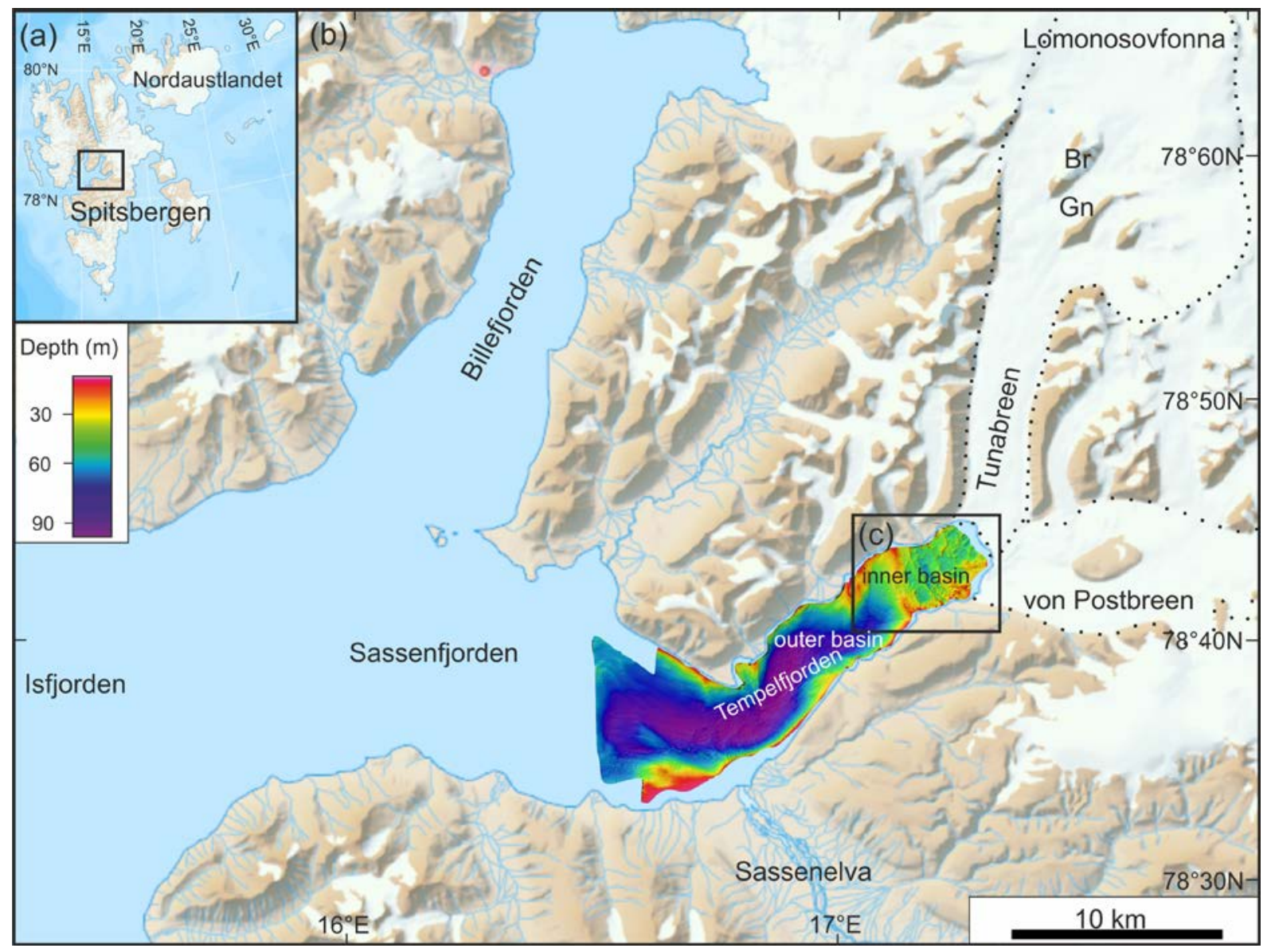

Fig.1. Site map. (a) The location of the Isfjorden fjord system in central Spitsbergen. (b)

Location of Tunabreen, von Postbreen and Tempelfjorden. Dashed lines outline the glacier systems of Tunabreen and von Postbreen. Br and Gn mark the locations of Bromsfjella and Gnombreen, respectively. (c) The black rectangle shows the main study area in the inner part of Tempelfjorden (Fig.4). Background maps are from Svalbardkartet (Norwegian Polar Institute, NPI).

\section{Geological and glaciological setting}

Tunabreen is an outlet glacier of the Lomonosovfonna ice cap that terminates at the head of Tempelfjorden, the easternmost branch of Isfjorden, Spitsbergen (Fig. 1). Tempelfjorden is about $14 \mathrm{~km}$ long, up to $5 \mathrm{~km}$ wide, and has a surface area of nearly $57 \mathrm{~km}^{2}$. The maximum water depth is $110 \mathrm{~m}$. The sedimentary environment in Tempelfjorden has been influenced mainly by Tunabreen, its neighboring glacier von Postbreen, and the 
Sassenelva River during the late- and post-glacial period. Changes in the sediment sources and sedimentation conditions have been suggested to reflect the multiple advances and retreats of the glacier fronts during the Holocene (Forwick et al. 2010).

During the early and mid-Holocene between 10-5 ka BP, tidewater glaciers were most likely absent from the Isfjorden area or at least reduced in size (Mangerud et al. 1992; Svendsen \& Mangerud 1997; Forwick \& Vorren 2009). They re-advanced into the fjord during the late Holocene around $4 \mathrm{ka} \mathrm{BP}$, and reached their most recent maxima during the Little Ice Age (LIA) advance around 1850 AD (Svendsen et al. 1996; Plassen et al. 2004; Forwick \& Vorren, 2009). The confluent von Postbreen and Tunabreen glacier system reached its late Holocene maximum position in the 1870 s, probably at the culmination of a surge (Plassen et al. 2004). This event produced a large terminal moraine with debris-flow lobes on its distal slope, similar to those observed in front of other tidewater surging glaciers in Svalbard (Plassen et al. 2004; Ottesen \& Dowdeswell, 2006; Ottesen et al. 2008).

After the 1870 advance, von Postbreen appears to have been quiescent and in continuous retreat, and is now entirely land-based. Tunabreen remained in contact with the fjord floor and underwent general retreat interrupted by surges in the 1930s, 1970s and the early 2000s, with each subsequent surge being less extensive than the previous one. During its most recent surge in 2003-2005, Tunabreen advanced about $2 \mathrm{~km}$. The rather regular 40-year surge cycle of Tunabreen is the shortest known in Svalbard; many of Svalbard's glaciers have surge cycles of over one hundred years (Dowdeswell et al. 1991). The short surge cycle of Tunabreen and the diverse observational record for this glacier, therefore, provides a unique opportunity to study the imprint of repeated surge events on the seafloor morphology.

\section{Datasets and Methods}


Mapping and analysis of the submarine landforms and the terminus positions of Tunabreen in the inner part of Tempelfjorden is based on multibeam-bathymetric, remotesensing, and published data, including ice-marginal positions and their chronology. The multibeam-bathymetric data were acquired with a Kongsberg EM3002, a $300 \mathrm{kHz}$ multibeam echosounder system by the Norwegian Hydrographic Service from $3^{\text {rd }}$ to $7^{\text {th }}$ July, 2011. The data were processed by applying optimal sound-velocity profiles to determine accurate water depths and gridded into an isometric grid with cell size of $5 \times 5 \mathrm{~m}$ in the Caris and QPS Fledermaus softwares. The UTM 33N projection was used with the WGS 84 datum. Satellite images (Landsat, ASTER, Envisat and TerraSAR-X), aerial photographs, and topographic maps were used for establishing the glacier margin positions between the 1970s and 2012. Terminus positions prior to the 1970s are based on published data (De Geer 1910; Liestøl 1969; Plassen et al. 2004; see Table 1 for a summary of data sources). All images were georeferenced or reprojected to the UTM 33N projection (WGS84 datum) in order to facilitate correlation with the multibeam-bathymetric data. The Landsat data contain images collected during the summer months as well as in the winter months (Table 1). The ASTER images were all obtained during the summer months, June-September. The wideswath-mode SAR images of the Tunabreen area were taken by the European Space Agency (ESA) Envisat satellite during late summer.

By analyzing images taken during different periods of the year (summer and winter) and by combining data from different sources, a quasi-continuous record of glacier terminus fluctuations has been obtained. Additionally, high spatial resolution data were obtained during 2013 and early 2014 on the annual cycle of ice-front activity of Tunabreen using TerraSAR-X data. Feature tracking a pair of TerraSAR-X images provides glacier surface velocities by detecting the movement of identifiable objects, speckle patterns or phase changes in the image samples. Ice margins and submarine landforms were tracked and digitized in 
ArcGIS. Cloud free images taken during the summer months were chosen for tracking the ice margins and crevasse positions.

Table 1. Summary of data types and sources used for mapping the terminal position of Tunabreen.

\begin{tabular}{|c|c|c|}
\hline Data type and details & $\begin{array}{l}\text { Terminus position data } \\
\text { acquired (dd/mm/yy) or } \\
(\mathrm{mm} / \mathrm{yy}) \text { or }(\mathrm{yyyy})\end{array}$ & Source \\
\hline \multicolumn{3}{|l|}{ Published data } \\
\hline Liestøl (1969) & 1924-1932 & Mapped photogrammetrically \\
\hline Hodgkins and Dowdeswell (1994) & 1966-1971 & Aerial photographs \\
\hline Plassen et al. (2004) & \begin{tabular}{|l}
1870 \\
1882 \\
1896 \\
1908 \\
1930 \\
1966 \\
1971
\end{tabular} & $\begin{array}{l}\text { Topographic maps and aerial image from } \\
\text { the Norwegian polar institute. } \\
\text { Maps by De Geer } 1910 \text {. }\end{array}$ \\
\hline $\begin{array}{l}\text { Norwegian Polar Institute (NPI) } \\
\text { maps (1:100,000 scale) }\end{array}$ & $\begin{array}{l}1990 \\
1993\end{array}$ & \\
\hline \multicolumn{3}{|l|}{ Satellite imagery } \\
\hline $\begin{array}{l}\text { Landsat MSS } \\
\text { (80 m pixel resolution) }\end{array}$ & $\begin{array}{l}09 / 04 / 75 \\
18 / 07 / 76 \\
24 / 07 / 79 \\
19 / 10 / 82\end{array}$ & $\begin{array}{l}\text { USGS Earth Explorer } \\
\text { (https://earthexplorer.usgs.gov) }\end{array}$ \\
\hline $\begin{array}{l}\text { Landsat TM } \\
\text { (30 m pixel resolution) }\end{array}$ & $\begin{array}{l}26 / 06 / 88 \\
27 / 07 / 06\end{array}$ & $\begin{array}{l}\text { Global Land Cover Facility } \\
\text { (www.landcover.org) }\end{array}$ \\
\hline $\begin{array}{l}\text { Landsat ETM+ } \\
\text { (30 m pixel resolution) }\end{array}$ & $\begin{array}{l}09 / 07 / 99 \\
17 / 06 / 01 \\
18 / 08 / 11 \\
19 / 07 / 12\end{array}$ & $\begin{array}{l}\text { USGS Earth Explorer } \\
\text { (https://earthexplorer.usgs.gov) }\end{array}$ \\
\hline $\begin{array}{l}\text { ASTER } \\
\text { (15 m pixel resolution) }\end{array}$ & $\begin{array}{l}13 / 06 / 02 \\
12 / 07 / 03 \\
25 / 07 / 04 \\
16 / 06 / 05 \\
01 / 08 / 10\end{array}$ & $\begin{array}{l}\text { Land Processes Distributed Active } \\
\text { Archive Center } \\
\text { (http://LPDAAC.usgs.gov) }\end{array}$ \\
\hline $\begin{array}{l}\text { ENVISAT SAR } \\
\text { (150 m resolution) }\end{array}$ & $\begin{array}{l}2007 / 10 \\
2008 / 10 \\
\end{array}$ & European Space Agency \\
\hline TerraSAR-X (2m resolution) & $03 / 13-02 / 14$ & DLR (German Space Agency) \\
\hline \multicolumn{3}{|l|}{ Aerial photographs } \\
\hline $\begin{array}{l}\text { NPI aerial photographs } \\
(1: 50,000 \text { scale })\end{array}$ & $\begin{array}{l}20 / 08 / 95 \\
27 / 07 / 04 \\
02 / 08 / 09\end{array}$ & Norwegian Polar Institute (NPI) \\
\hline
\end{tabular}

\section{Results}

\subsection{History of terminus fluctuations in Tempelfjorden}


Tidewater margin fluctuations in Tempelfjorden from 1870-2012, encompassing the surges of Tunabreen and von Postbreen, are shown in Fig. 2. The westernmost mapped margin, located $4.5 \mathrm{~km}$ from the Tunabreen marginal position in 2012 is the LIA maximum of von Postbreen in 1870 as mapped by De Geer (1910) (Fig. 2). This represents the maximum glacier extent in Tempelfjorden during the Holocene and the culmination of LIA glacier regrowth following an extended period of stepwise retreat after the last glacial (Forwick et al. 2010). The maximum extent of von Postbreen could either reflect a surge event or a period of strong positive mass balance. The position of the von Postbreen terminus was also mapped in 1882, 1896 and 1908 by De Geer (1910), indicating a retreat of 2 km in 40 years (Fig. 2). 


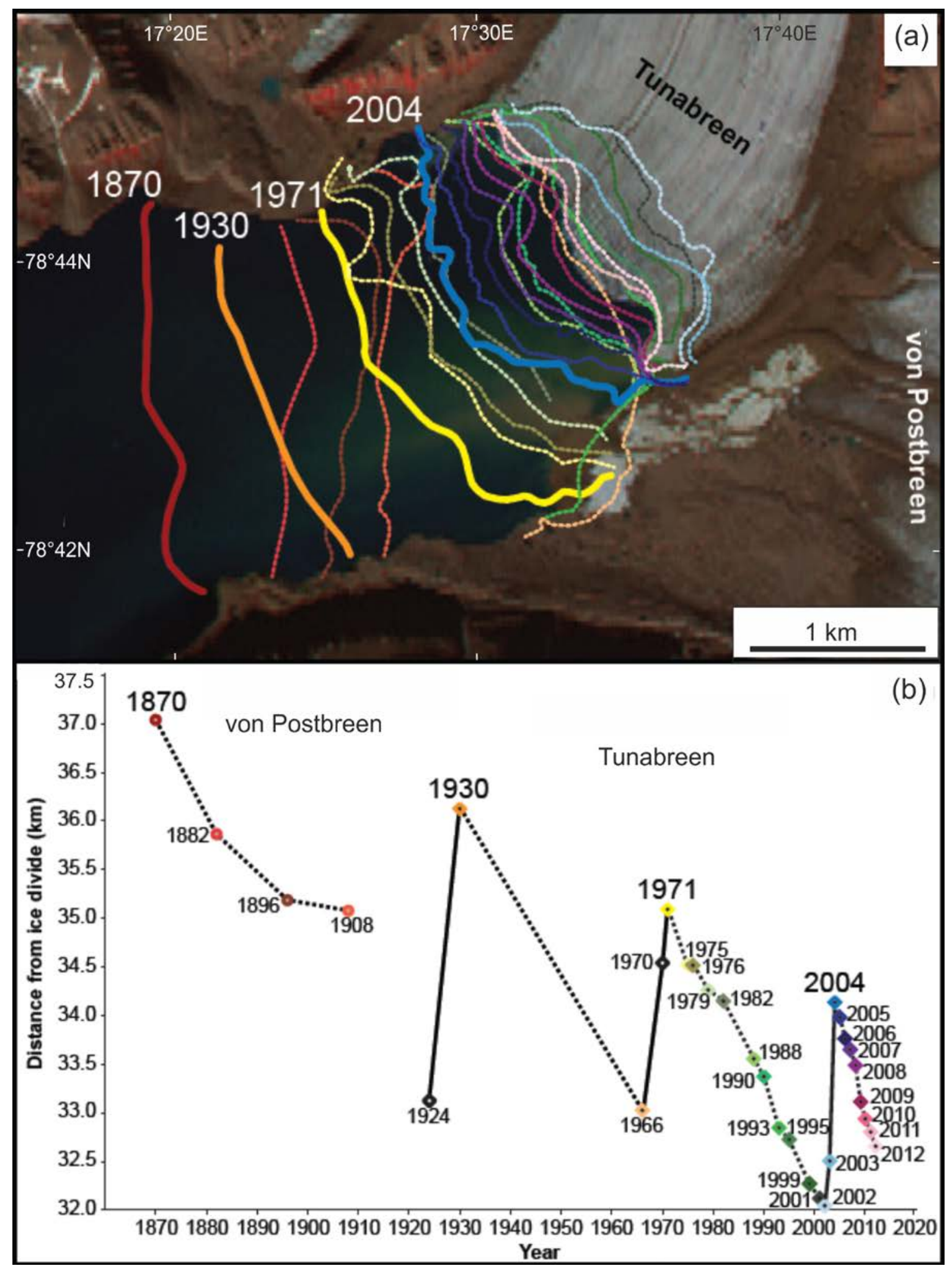

Fig. 2. Glacier terminus fluctuations in Tempelfjorden between 1870-2012. (a) Terminus positions derived from a range of data sources (see table 1) overlain on a 2009 aerial image (NPI). Thicker lines show surge maximums. (b) Terminus positions plotted as distance along a centre line from Lomonosovfonna ice divide (derived from Hagen et al. 1993). The 1924 
and 1970 positions are not mapped limits but are relative positions based on observations in Liestøl (1969) and Hodgkings \& Dowdeswell (1994).

Glacier retreat in Tempelfjorden continued until 1930, when Tunabreen surged to a position 1 km upfjord from the 1870 position of von Postbreen. The switch of the dominant flow unit from von Postbreen to Tunabreen during this advance is clear in oblique photographs published by Liestøl (1969), which show a small, pinched-out Tunabreen comprising $<25 \%$ of the coalescent terminus and a deflected medial moraine in 1924. This contrasts with the situation in 1932, where Tunabreen made up over a third of the advanced coalescent terminus and a straightened medial moraine is evident. Following the 1930s surge, Tunabreen retreated around $3 \mathrm{~km}$ during 36 years until the next mapped position in 1966, by which time von Postbreen had retreated onto land. Between 1966 and 1970, Tunabreen began to surge again and had advanced 2 km by 1971 (Hodgkins \& Dowdeswell 1994). The 1971 surge terminated $1 \mathrm{~km}$ upfjord from the 1930s surge maximum (Fig. 2). The retreat of the margin following the 1970s surge is well documented in satellite and aerial images and shows a stepwise retreat of $3 \mathrm{~km}$ in 31 years up to 2002 (Fig. 2).

Between June 2002 and August 2003, the Tunabreen margin began to advance, providing the first visible signs of the most recent surge (Fig. 3). The heavily-splayed 2004 margin delimits the surge maximum, recording a margin advance of $2 \mathrm{~km}$ to a position $1 \mathrm{~km}$ upfjord from the 1971 surge maximum. Up-glacier propagation of crevasses has been observed during the surge cycle, starting with crevasses only at the front of the glacier in 2002. In 2004 the crevasses had propagated along the entire length of the glacier (Fig. 3). The surge terminated sometime between July 2004 and June 2005. After 2005 the terminus underwent a stepwise retreat of $1.5 \mathrm{~km}$ to its 2012 position at rates of $100-300 \mathrm{~m} \mathrm{a}^{-}$ 


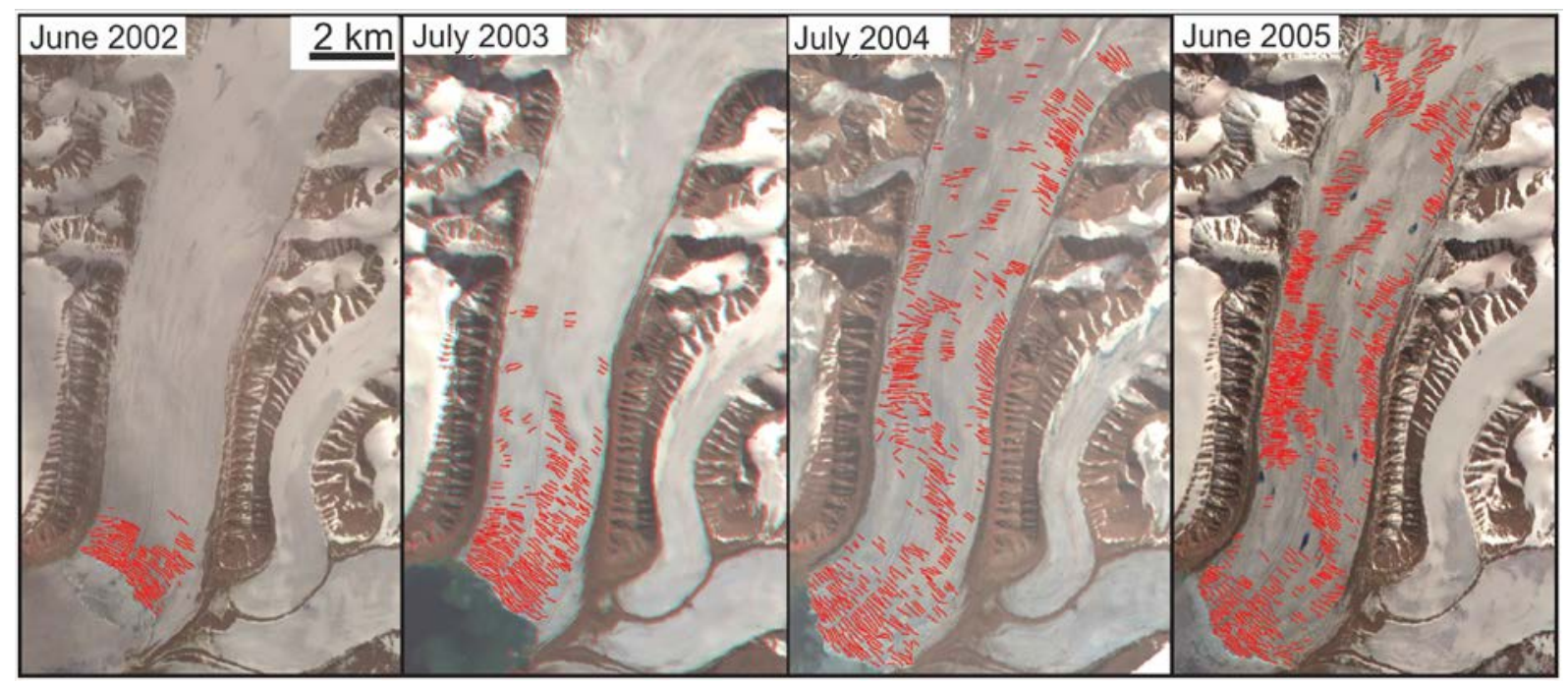

Fig. 3. Landsat satellite images showing up-glacier propagation of crevasses during the most recent surge of Tunabreen between 2002-2005.

Fig. 2 demonstrates that each surge of Tunabreen has been characterized by an advance of 2 $\mathrm{km}$ and has reached a maximum position $1 \mathrm{~km}$ up-fjord from the previous surge limit. Furthermore, Fig. 2 suggests that Tunabreen has a remarkably short, and over the time period where data is available, consistent surge-cycle length in the context of Svalbard surge-type glaciers (only Blomstrandbreen at c. 47 years is comparable; Mansell et al. 2012).

\subsection{Description and interpretation of submarine landforms}

Tempelfjorden comprises of two basins, a larger outer basin and a smaller inner basin (Fig. 1). The outer basin has a maximum depth of $110 \mathrm{~m}$, whereas the inner basin is $60 \mathrm{~m}$ deep at its maximum. The von Postbreen terminal moraine ridge, deposited at its LIA maximum extent in the 1870s (Fig. 2), separates the two basins. The landforms in the outer part of Tempelfjorden have been described in previous studies (Plassen et al. 2004; Forwick et al. 2010). These landforms include the von Postbreen terminal moraine and two debris-flow lobes on its distal slope. The surface of the stratigraphically lower debris-flow lobe has been 
deformed into thrust moraines (De Geer 1910; Plassen et al. 2004; Forwick et al. 2010). In this study, we focus on the geomorphological features in the previously unexplored inner part of Tempelfjorden (Fig. 4). 


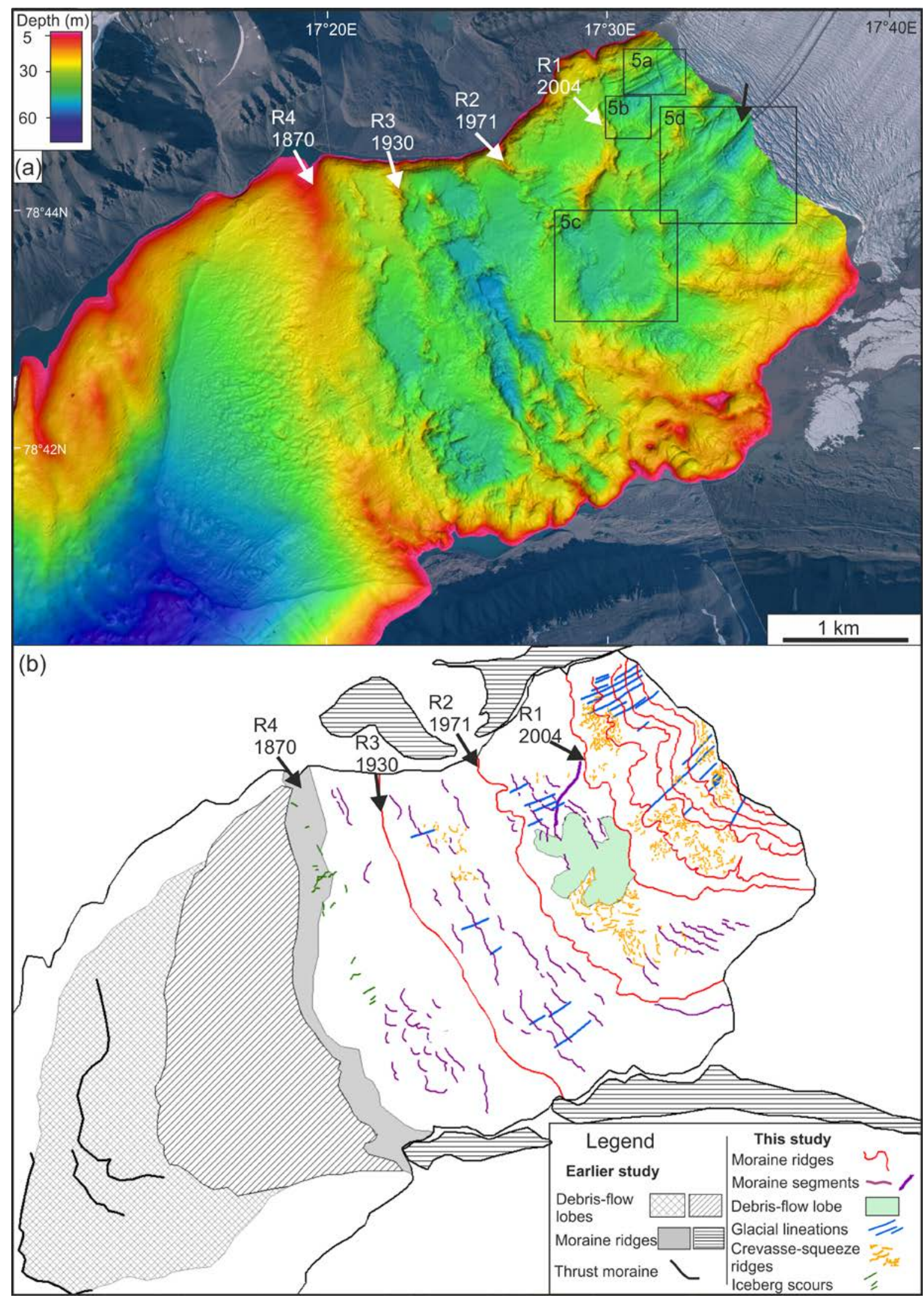

Fig.4. The glacial landform record in Tempelfjorden. (a) Multibeam-bathymetric image showing the geomorphology in the inner part of Tempelfjorden, superimposed on a NPI 
aerial image from 2009. Black rectangles show the location of the images in Fig. 5. B lack arrow points towards glacial lineation which corresponds with the medial moraine of the glacier. (b) Map of interpreted submarine landforms. Mapping of the R4 ridge, subaerial moraine ridges, older debris-flow lobes and thrust moraines is based on Plassen et al. (2004) and Forwick et al. (2010).

\subsubsection{Elongate streamlined bedforms: Glacial lineations}

\section{Description}

Elongate, streamlined bedforms, oriented parallel to the fjord axis, occur in several places on the seafloor in Tempelfjorden down to water depths of $50 \mathrm{~m}$ (Fig 4). The elongation ratio of the ridges is 5:1. Typically, these bedforms rise between 1 and $3 \mathrm{~m}$ above the surrounding seafloor (Fig. 5a, 5e). Ridge width varies between 50-150 m and they are usually around 500 $\mathrm{m}$ long. However, some of the ridges closest to Tunabreen are up to $1000 \mathrm{~m}$ in length. The distance between the crests and troughs of these bedforms is typically 50-100 m. Some of the streamlined bedforms are superimposed on large streamlined mounds which are up to $10 \mathrm{~m}$ high. We have identified streamlined bedforms in front of the present glacier terminus, west of the 2004 surge maximum, and in the area between the 1930s and 1970s surge limits (Fig. 4). Adjacent to the present glacier front, one of the streamlined bedforms appears to be coincident with the debris-rich medial moraine of Tunabreen, pointed out with a black arrow (Fig. 4a).

\section{Interpretation}

The elongated, streamlined bedforms are interpreted as glacial lineations produced by softsediment deformation at the glacier-bed interface. The lineations form parallel to ice flow, in the presence of a saturated deformable till (King et al. 2009). Glacial lineations are typical of fast-flowing glacier ice (Stokes \& Clark 2002; Ottesen \& Dowdeswell 2006; King et al., 
2009), and are therefore consistent with a surge advance of Tunabreen.

Adjacent to the present glacier front, one of the streamlined bedforms appears to be coincident with the debris-rich medial moraine of Tunabreen (Fig. 4a). The unusually large size of the ridge suggests that it is not a pure glacial lineation, but could be an overridden medial moraine.

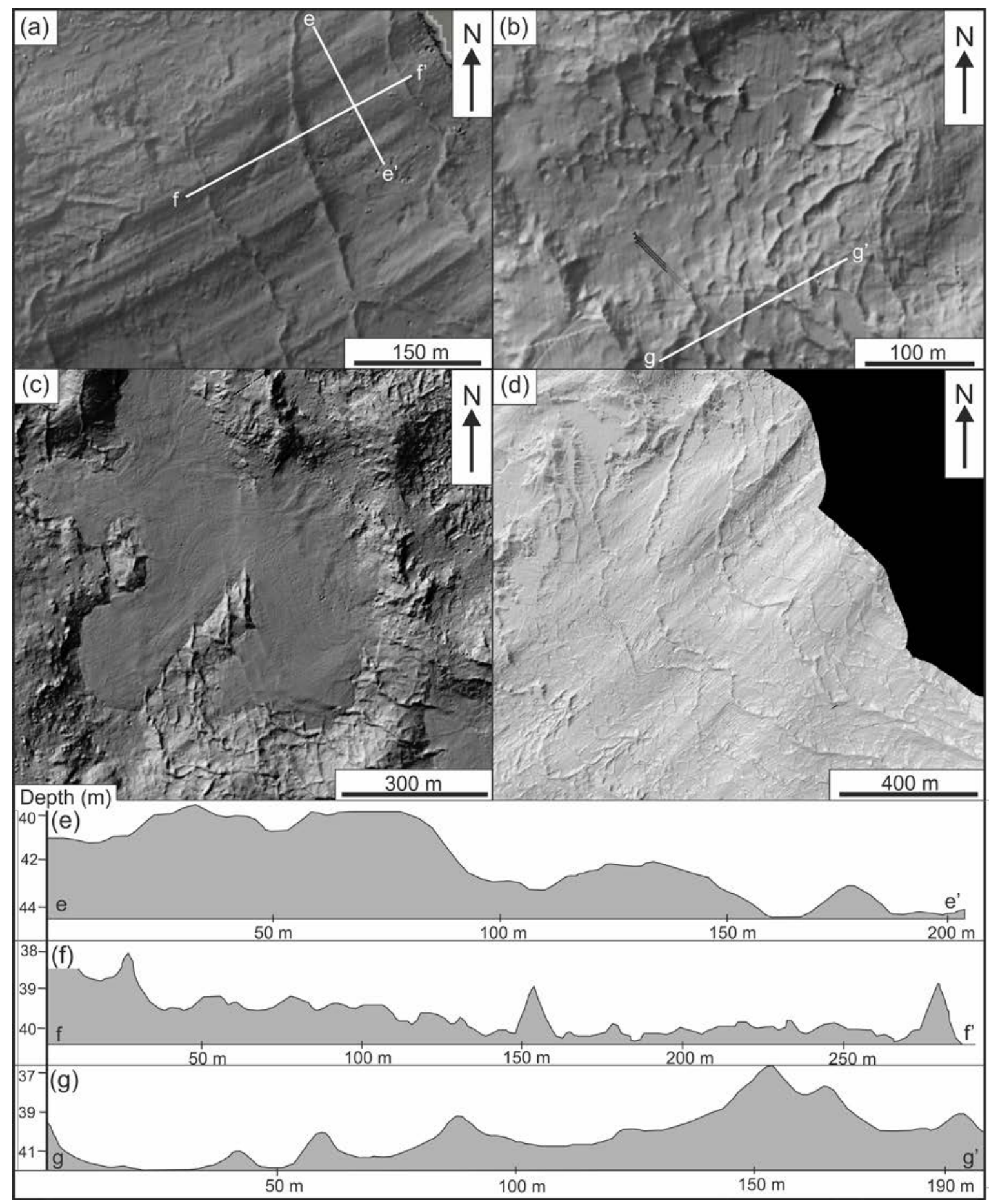


Fig.5. Examples of the landforms in Tempelfjorden. (a) Glacial lineations. (b) Crevassesqueeze ridges. (c) Debris-flow lobe, covering older crevasse-squeeze ridges. (d) Annual retreat moraines superimposed on glacial lineations. (e) Seafloor profile of the glacial lineations. (f) Seafloor profile of annual retreat moraines. (g) Seafloor profile of crevassesqueeze ridges.

\subsubsection{Large transverse ridges: Surge terminal moraines}

\section{Description}

Four NW-SE aligned, large cross-fjord ridges occur on the seafloor of the inner Tempelfjorden and are oriented transverse to the fjord axis. The innermost ridge, R1, is located $1.4 \mathrm{~km}$ from the 2012 glacier front and curves across the entire, $3 \mathrm{~km}$-wide fjord (Fig. 4). The ridge is 6-8 $\mathrm{m}$ high and $50 \mathrm{~m}$ wide. The second ridge, $\mathrm{R} 2$, is located $2.2 \mathrm{~km}$ from the 2012 glacier front, is 10-15 m high, 50-100 m wide and $3 \mathrm{~km}$ long. The third ridge, R3, is located $3 \mathrm{~km}$ from the 2012 glacier front. The ridge has a width of 150-200 m, extends 3.5 $\mathrm{km}$ across the entire fjord and has an average height of $10 \mathrm{~m}$. The fourth ridge, $\mathrm{R} 4$ is $3.5 \mathrm{~km}$ long and $1 \mathrm{~km}$ wide. It is maximum $70 \mathrm{~m}$ high and contains multiple crestlines. Large debrisflow lobes are present on the distal side of the R4 ridge. The ridge and the debris-flow lobes are described in further detail by Hagen et al. (1993), Plassen et al. (2004) and Forwick et al. (2010). In general, the large transverse ridges are asymmetric, with $10^{\circ}-20^{\circ}$ steep iceproximal slopes, and distal slopes between $5^{\circ}-10^{\circ}$. The R4 ridge has significantly gentler slopes of $2^{\circ}-6^{\circ}$. The ridges are typically multi-crested along their entire lengths. The exception is the R1 ridge, which is mainly single-crested, but has some multi-crested sections.

\section{Interpretation}

The locations of the large ridges correlate well with the ice-terminus positions of Tunabreen as mapped from remote-sensing and published data (Fig. 2). The easternmost ridge, R1, 
displays a strong spatial correlation with the maximum position of the glacier front in 2004 (Fig. 4). The glacier position during the 1970's surge according to Plassen et al. (2004) correlates well with the position of the second large submarine moraine, R2, and the position of R3 correlates with the mapped position of the glacier front during the 1930s (Plassen et al. 2004). We therefore interpret the ridges R3, R2 and R1 as terminal moraines formed during the surge maxima in 1930, 1971 and 2004, respectively.

The westernmost large transverse ridge, R4, is contiguous with the subaerial moraines on both sides of Tempelfjorden, which together are interpreted as the latero-terminal moraine system formed by von Postbreen during its LIA maximum (De Geer 1910; Hagen et al. 1993; Plassen et al. 2004). The R4 ridge with multiple crestlines, large debris-flows lobes and numerous dislocated sediment blocks on its distal slope is morphologically similar to terminal moraines formed by surges in other Svalbard fjords (cf. Ottesen \& Dowdeswell, 2006; Ottesen et al. 2008). Kristensen et al. (2009) have argued that this type of moraine forms by bulldozing of marine mud in front of the surging glacier with quasi-continuous failure of weak, saturated sediments on the moraine front. In contrast, large debris-flow lobes are not present on the distal slopes of ridges R1-R3, although the asymmetric, multi-crested form of these ridges indicates that they were also likely formed by ice push (cf. Boulton et al. 1996). We suggest that the absence of large debris- flow lobes adjacent to the R1-R3 ridges reflects lower sediment availability because of the relatively short surge interval of only 40-60 years, during which there would have been little time for accumulation of mud on the fjord floor between the surge events. Furthermore, much of the pre-existing soft sediment (sediment that accumulated on the sea floor pre-1870) had been pushed up into the LIA moraine, which helps to explain the size of the 1870 moraine (R4) when compared to the R1-R3 moraines. 
The large transverse ridges in Tempelfjorden are in general smaller, in both height and width, than surge terminal moraines mapped elsewhere in Svalbard (Ottesen \& Dowdeswell 2006; Ottesen et al. 2008). The von Postbreen LIA moraine, which is up to $1 \mathrm{~km}$ wide, is most similar to the surge moraines described in Rindersbukta and Van Keulenfjorden in southern Spitsbergen (Ottesen et al. 2008). The surge moraines of Borebreen located on the northern side of Isfjorden display similar characteristics, although with slightly larger dimensions than the innermost ridges (R1-R3) in Tempelfjorden (Ottesen \& Dowdeswell 2006).

\subsubsection{Sediment lobe at the 2004 ice margin: Debris-flow lobe}

\section{Description}

No large debris-flow lobes were observed on the distal sides of ridges R1-R3.

A small sediment lobe can, however, be observed distal to the terminal moraine R1 (Fig. 5c). The lobe has a maximum length of $0.7 \mathrm{~km}$ and a width of $0.9 \mathrm{~km}$. It comprises three lobeshaped protuberances at its front. It is located in 30-50 m water depth adjacent to the moraine ridge. The sediment lobe covers a small depression in the fjord bathymetry and partly overrides older ridges. The surface of the lobe has a smooth appearance, but the overridden ridges are clearly visible in the southern section of the sediment lobe.

\section{Interpretation}

The sediment lobe on the distal side of R1 has been interpreted as a debris-flow lobe based on its shape as well as on the fact that the lobe onlaps onto small moraine ridges. The short duration of the 2004 surge and sedimentation rates of $3800 \mathrm{~cm} \mathrm{ka}^{-1}$ near the present glacier front (Forwick et al. 2010) further indicates that the sediment lobe originated as a debris-flow from the ridge itself rather than due to gradual sediment accumulation. Similar glacigenic debris-flow lobes have been discovered in front of marine-terminating surge-type glaciers in 
Svalbard (Ottesen \& Dowdeswell 2006; Ottesen et al. 2008). These lobes are, however, much larger, having similar dimensions as the debris-flow lobe originating from the von Postbreen LIA moraine (Ottesen et al. 2008).

\subsubsection{Geometrical ridge networks: crevasse-squeeze ridges}

\section{Description}

There are several areas in the inner part of Tempelfjorden where small, symmetrical sediment ridges form dense, cross-cutting networks (Fig. 4). The ridge networks are most widespread inside the 2004 surge moraine (R1), although an extensive, double-arcuate shaped network is also found between R1 and R2 on a bathymetric high. No ridge networks have been observed down-fjord of the 1930s surge limit. The individual ridges are commonly up to $3 \mathrm{~m}$ high, but can be less than $1 \mathrm{~m}$ high, and are between 5-10 m wide (Figs. 5b, 5g). The ridges are commonly between 10-20 m long; however the larger ones can be up to $100 \mathrm{~m}$ long. Many of the ridges are oriented approximately parallel or at right angles to former ice-front positions, although oblique ridges are also common. In places, intersecting ridges with two dominant directions form rhombic patterns (Fig. 5b).

\section{Interpretation}

The crosscutting network of ridges has been interpreted as crevasse-squeeze ridges. The ridge network between the R1 and R2 ridge consist of a combination of crevasse-squeeze ridges and fjord-transverse ridges (see section 4.2.6). Networks of small, sharp-crested ridges also occur on land, particularly on the foreland of von Postbreen (Figs. 6a, b). In addition, numerous debris-rich structures are exposed in ice-cliff sections at the margins of Tunabreen (Fleming et al. 2013; Lovell et al. in prep, Fig. 6c). The structures extend upwards from the bed and are infilled with basal till. In some instances, continuity can be demonstrated between till-filled structures and low ridges of till exposed by ice retreat (Fig. 
$6 d)$.

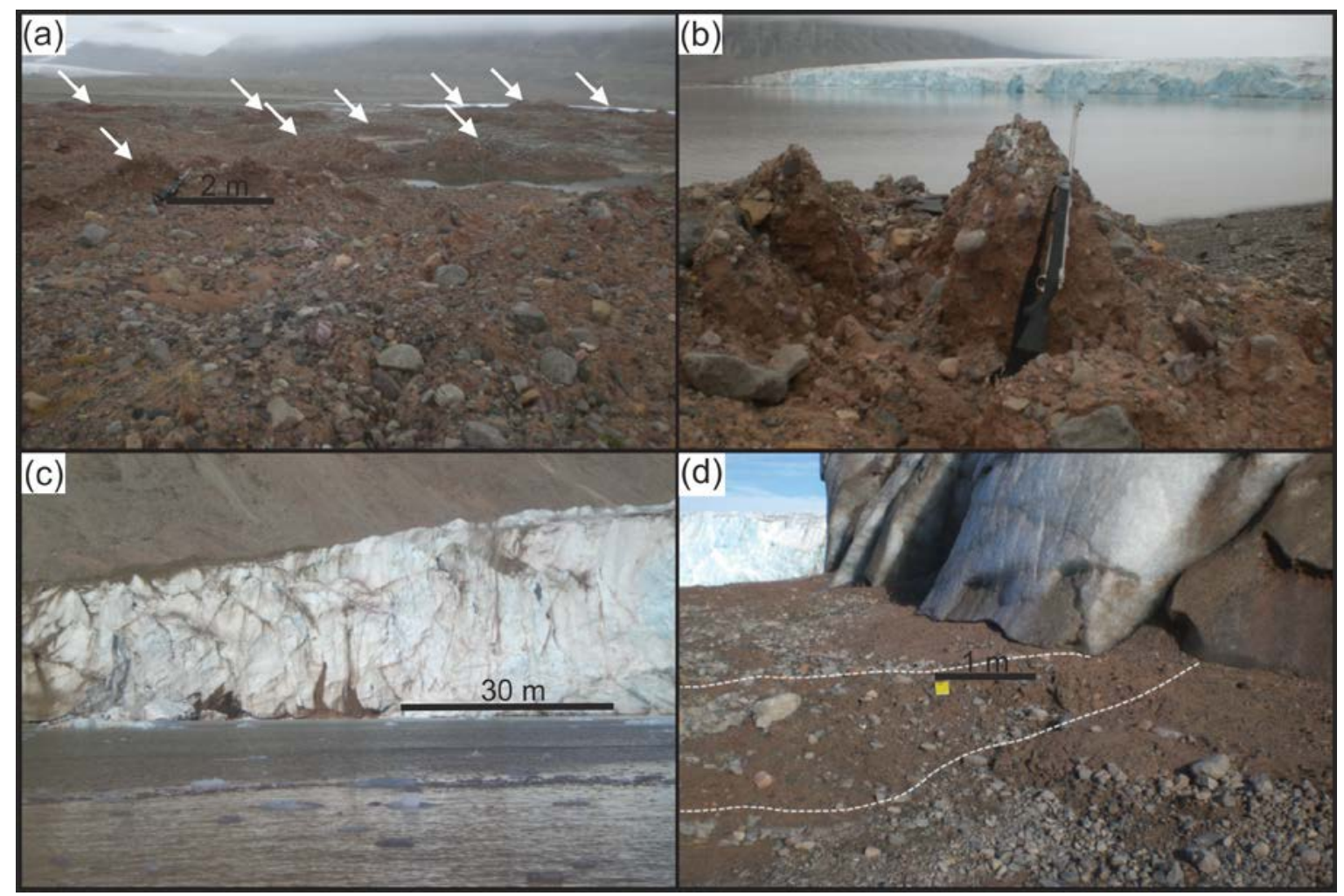

Fig.6. Examples of terrestrial ridges and englacial debris-rich structures in August 2011. (a)

Part of the ridge network on the southern side of Tempelfjorden. Individual ridges are

arrowed. View is towards von Postbreen. (b) Detail of an individual sharp-crested ridge within the network on the southern side of Tempelfjorden (rifle for scale). (c) Vertical debris-rich structures within Tunabreen ice cliff. (d) Low ridge melting out from the englacial debris-rich structure in Tunabreen ice cliff. White dashed lines denote the ridge.

The ridge networks are similar to those described previously from the forelands of other surging glaciers in Svalbard (e.g. Bennett et al. 1996; Ottesen \& Dowdeswell 2006). The close similarity of the ridge networks on the fjord floor to those on land, and the association between terrestrial examples and debris-rich structures in the ice of Tunabreen, demonstrates that they form by injection of debris into basal fractures and subsequent melt-out. During glacier surges, basal crevasses can form in regions of longitudinal extension (Rea \& Evans 2011) and/or in regions of intense compression near surge fronts 
(Lawson et al. 2000; Kristensen \& Benn 2012). In both cases, basal fracturing and the upward injection of till are encouraged by subglacial water pressures close to the ice overburden pressure. It is difficult to determine which of these is most applicable to the Tempelfjorden ridges based solely on their geometric characteristics and location. However, the surface crevasse pattern at the splayed glacier front in 2004 (see Fig. 11a in Fleming et al. 2013) (Fig. 7) supports the presence of a complex stress regime, as it shows both large transverse crevasses (indicative of longitudinal extension) and, at the very front, oblique crevasses (indicative of transverse extension). This pattern of surface crevasses (Fig. 7b) shows close correspondence with that of the ridge networks in the central part of the fjord, indicating that the latter reflect predominantly extensional stresses (longitudinal and transverse) during the 2004 surge. The mapped crevasses (Fig. 7b) show close correspondence to the position of mapped submarine crevasse-squeeze ridges. The crevasse-squeeze ridges are commonly present in the same areas as complex patterns of transverse, longitudinal and oblique surface crevasses.

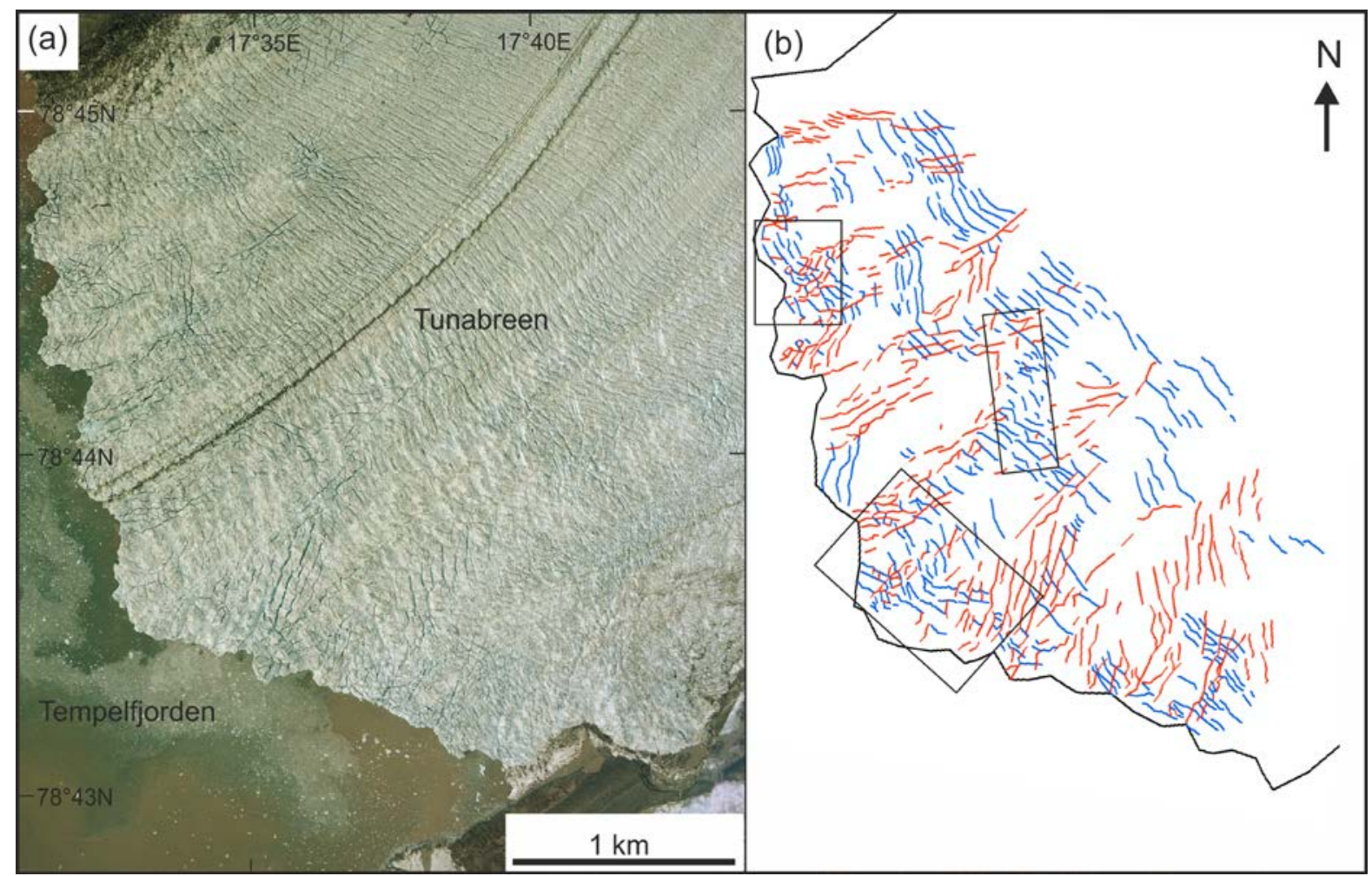

Fig. 7. The terminus of Tunabreen during the 2004 surge. (a) Aerial photomosaic (NPI), 
showing the heavily crevassed glacier front. (b) Mapped crevasses at the glacier front: transverse crevasses in blue, longitudinal and oblique crevasses in red. Black boxes outline main areas of crevasse-squeeze ridges.

\subsubsection{Small transverse ridges: Annual retreat moraines}

\section{Description}

A number of relatively closely-spaced, sub-parallel cross-fjord ridges can be observed within the 2004 surge limit. The ridges are aligned approximately perpendicular to the fjord axis and extend into the shallow-water areas along the fjord margins. They are 2-4 m high and 10-20 m wide, with an average spacing of 100-300 m. The ridges are curvi-linear in planform and asymmetric in cross-profile. The average proximal slope angle is $10^{\circ}$, while the average distal slope angle is $8^{\circ}$. The ridges are superimposed on the glacial lineations in front of the current glacier front (Figs. 5d, 5f).

\section{Interpretation}

The transverse ridges can be matched with annual positions of the front of Tunabreen determined from satellite imagery, equating to one ridge for each year between 2005 and 2009, which marks the inner limit of our survey data (Fig. 8). Therefore, the ridges can be confidently interpreted as annual moraines, corroborating previous interpretations of similar transverse ridges in other Svalbard fjords (e.g. Solheim 1991; Ottesen \& Dowdeswell 2006; Ottesen et al. 2008). The moraines are however much more lobate than the glacier margin delineations, indicating that the grounding line has a different form from the top of the glacier. The indentations of the grounding line are likely related to subglacial conduits and/or bathymetric deepenings. 


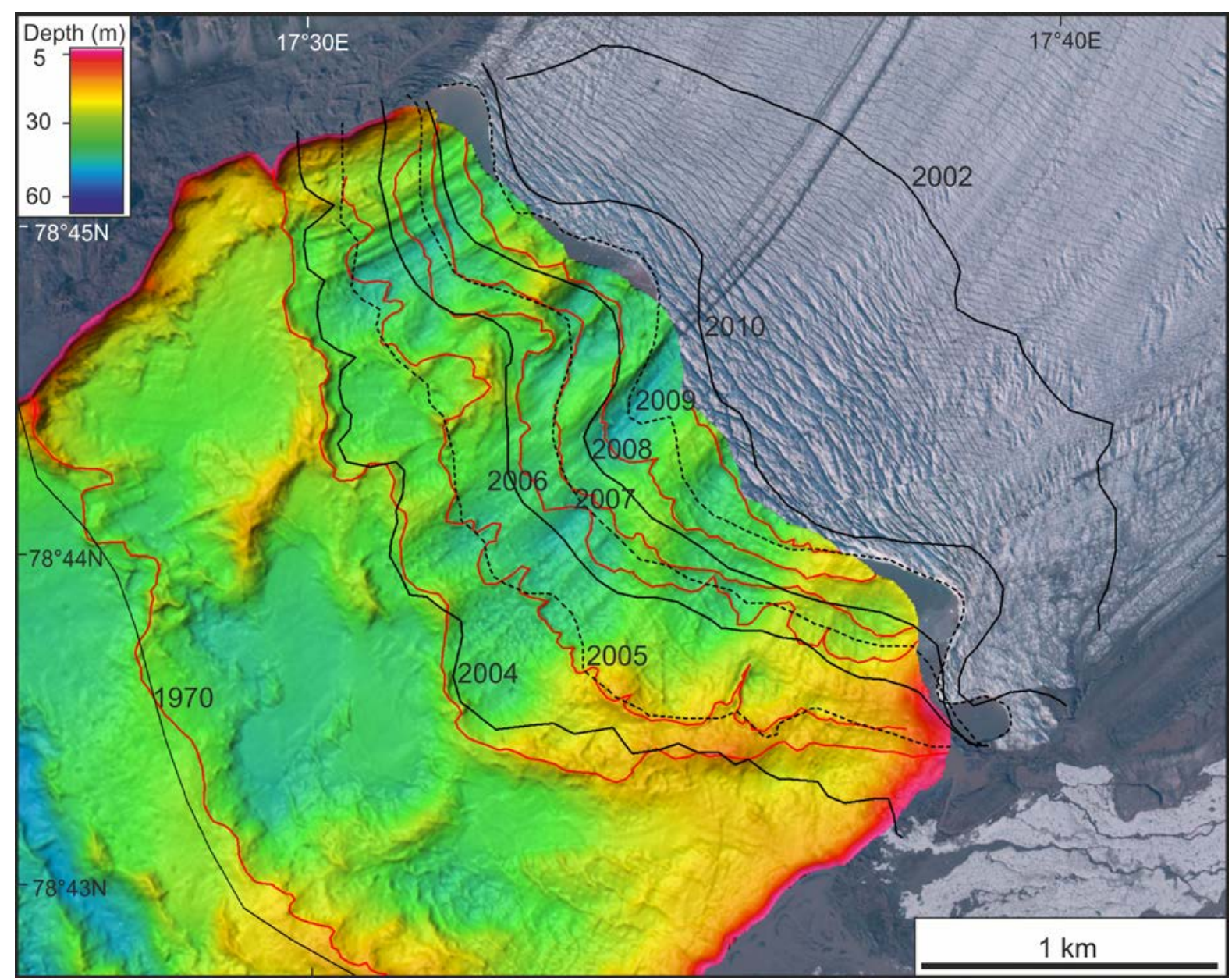

Fig. 8. Terminus positions from 2002-2010 (black lines) in relation to the submarine moraines (red lines). The terminal positions have been mapped from ASTER/Landsat and SAR images. The background shows an aerial image from 2009 (NPI).

The formation of annual moraine ridges in front of quiescent tidewater surge-type glaciers has been attributed to winter still-stands or minor re-advances (Solheim, 1991; Ottesen \& Dowdeswell, 2006; Ottesen et al. 2008). At Tunabreen, surface velocity and ice-front position data derived from TerraSAR-X satellite images demonstrate that the glacier front readvances during winter and spring, when calving rates are very low. Figure 9 shows an annual retreat of $150 \mathrm{~m}$ which includes a winter advance of $20 \mathrm{~m}$. Velocity data for early February 2014 are shown in Figure 10, and indicate that ice located a few hundred metres behind the calving front exhibits extending flow, with velocities at the terminus of up to $0.5 \mathrm{~m}$ 
day ${ }^{-1}$. The main trunk of the glacier, however, has no detectable motion, consistent with its quiescent state. This type of velocity pattern persists throughout the image series (January 2013-March 2014), with short-term variations in frontal speed relating to sea-ice extent and the buttressing effects of sea ice.

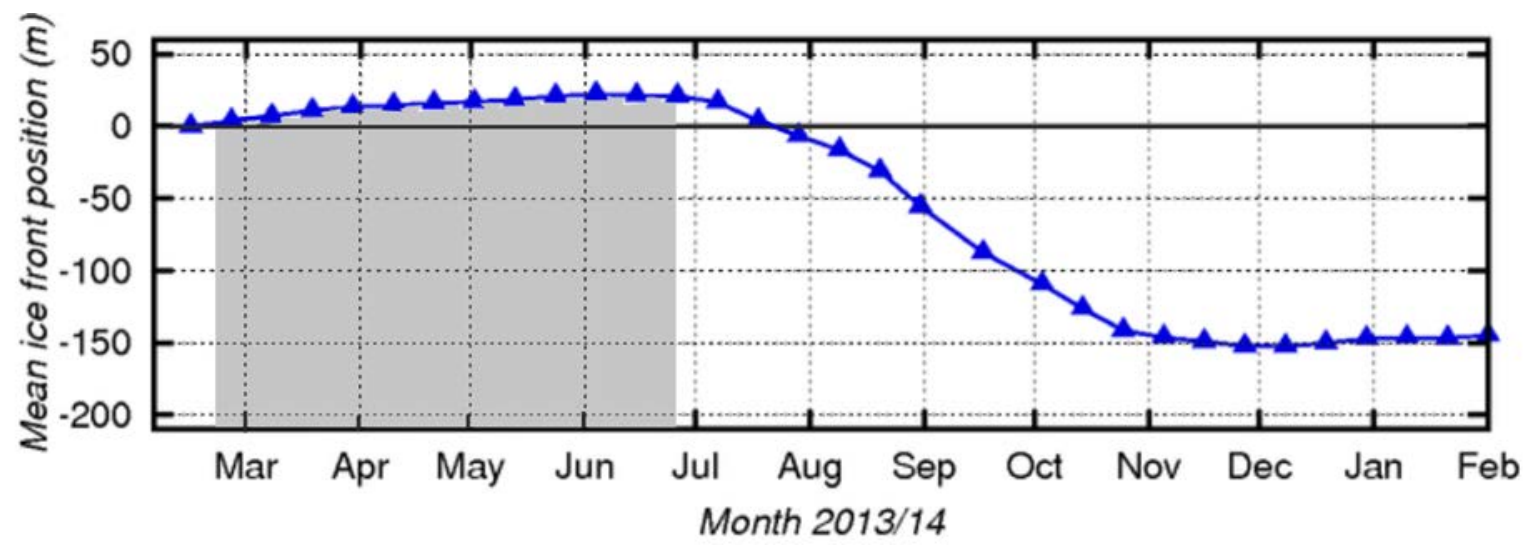

Fig. 9. Mean relative position of the terminus of Tunabreen during 2013 and early 2014. Note annual retreat of c. $150 \mathrm{~m}$ and winter advance of c. $20 \mathrm{~m}$. Grey area shows the period of fast sea ice in the inner part of Tempelfjorden (Norwegian meteorological institute).

During the summer and autumn months, calving rates exceed the rate of ice flow, and the glacier retreats. During winter, calving rates are very small, allowing the front to advance a few tens of metres. Therefore, for fjord-terminating surge-type glaciers winter push moraines can form even during quiescent phases. This is in contrast with the situation for terrestrial surge-type glaciers, the tongues of which downwaste in situ with no annual readvances of the front. The asymmetric cross-profile of the ridges further indicates that they have formed through ice push (cf. Boulton et al. 1996). Minor winter readvances may also be responsible for the buckling of sea ice in front of the glacier margin (e.g. Marchenko et al. 2012). 


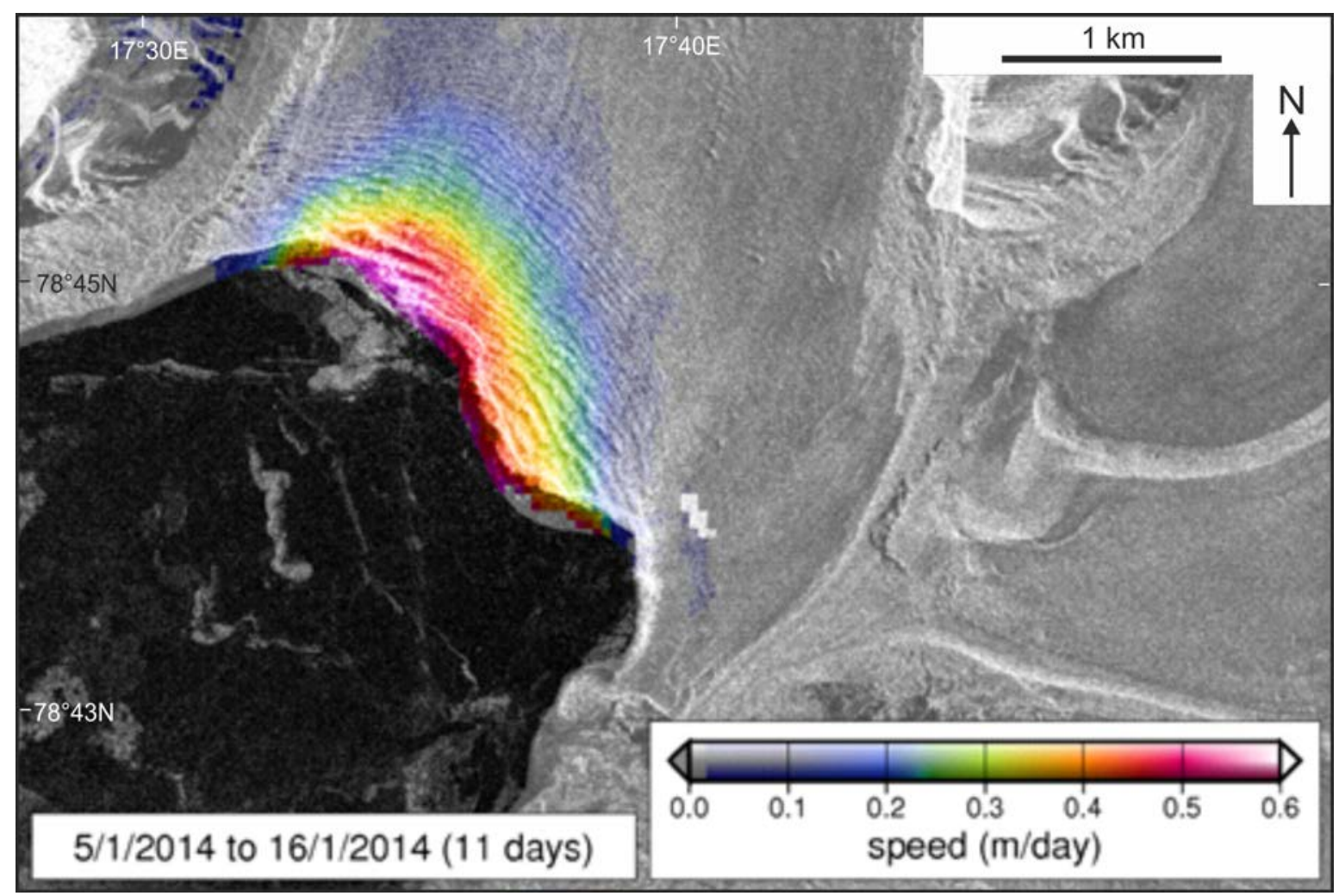

Fig.10. Surface speed of the terminus of Tunabreen during January 2014 derived from feature tracking a pair of TerraSAR-X images.

\subsubsection{Transverse to semi-transverse ridge segments: retreat moraines}

\section{Description}

Segments of small fjord-transverse ridges can be found between the R1 and R2 ridges (Fig.

4). The ridges are up to $1 \mathrm{~km}$ long, between 1-3 $\mathrm{m}$ high and 3-10 m wide. The ridges are not continuous across the fjord floor and are most visible on the southern side of the fjord as well as on the topographic highs in its central part. The spacing between the ridges on the SW side of the fjord is fairly regular, between $80-100 \mathrm{~m}$. The ridges are mainly asymmetric in crossprofile, with steeper proximal sides, which distinguishes them from a network of crevassesqueeze ridges, which are also present in the same area. Segments of transverse ridges also exist between the R2 and R3 ridges, as well as between the R3 and R4 ridges.

Subdued large-scale ridges are also present in the inner part of Tempelfjorden. These ridge 
segments are up to $15 \mathrm{~m}$ high, $150 \mathrm{~m}$ wide and $600 \mathrm{~m}$ long. They are oblique to the fjord and have been overprinted by glacial lineations, crevasse-squeeze ridges and retreat moraines.

\section{Interpretation}

The fjord-transverse ridges are similar to the annual retreat moraines proximal to the R1 ridge. They match the ice margin form of R1 and R2 (Fig. 2) and have therefore been interpreted as segments of small retreat moraines, formed after the 1970's surge. The rhombohedral pattern of some of the ridges in the area suggests that the ridge network consists of a mixture of retreat moraines and crevasse-squeeze ridges.

It is likely that the transverse ridges are continuous across the entire fjord, but the debris-flow lobe and sediment infill during the 2004 surge has buried parts of the ridges. Due to the close spacing and similarity of these ridges to the post-2004 annual retreat moraines these ridges were most likely formed annually. Due to the incompleteness of the geomorphological record this interpretation is somewhat ambiguous.

The transverse ridges between the R2 and R3 terminal moraines are similar to the ridges between the R1 and R2 moraines. The ridge segments distal to the R3 ridge are however larger in scale, being up to $10 \mathrm{~m}$ high and $30 \mathrm{~m}$ wide, suggesting that they have formed during longer still-stands of the glacier front or during shorter glacier advances.

The underlying large-scale ridges have been interpreted as overridden terminal moraines. They are similar to overridden terminal moraines described by Ottesen \& Dowdeswell (2006). These ridges have most likely formed by ice marginal processes during the older retreat phases of the glacier front. One of the ridges, just distal to the 2004 surge terminal moraine coincides with the position of the glacier front in 1908. It is therefore likely that these ridge segments have formed by the retreating glacier front of von Postbreen after the 1870 LIA maximum. The front of the glacier has most likely experienced periods of longer still stands, or shorter advance phases during general retreat. 


\section{Discussion}

Detailed data on the recent behavior of Tunabreen, including annual and seasonal variations in glacier extent, velocities, and observations of sea ice and glacial debris structures, have been studied together with high-resolution seabed morphology in inner Tempelfjorden. Direct links have been drawn between the observations of the recent glacier dynamics and newly formed sub-marine landforms. In particular, the observed changes in glacier dynamics since the 2004 surge have been directly linked to the submarine landforms. Furthermore, we have been able to correlate discrete winter advances of the glacier terminus with annual push moraine formation by using feature tracking in TerraSAR-X imagery.

The $40 \mathrm{~m}$ freeboard (height of the ice cliff above the water line) of Tunabreen in 2011 (Marchenko et al. 2012) suggests that the glacier was grounded during and following the 2004 surge event. Significant thinning of the glacier front (up to $30 \mathrm{~m}$ ) would be necessary for Tunabreen to become floating in the shallow inner part of Tempelfjorden. Therefore, the best preserved glacial lineations in the innermost part of Tempelfjorden most likely result from the latest, 2004 surge event. Figures 4a and 8 illustrate the link between the debris-rich belt in the glacier and one of the streamlined bedforms in front of the modern glacier margin that most likely represents a medial moraine. This particular medial moraine has its origin approximately $17 \mathrm{~km}$ up-glacier where the Tunabreen and Gnombreen glaciers converge south of the nunatak mountain of Bromsfljellet (Fig. 1). The deposition of the debris incorporated into the glacier by glacial erosion and slope processes at Bromfjellet forms the medial moraine at the glacier margin.

With increasing distance from the 2012 ice front, the glacial lineations are less common in the geomorphological record, most likely due to reworking by subsequent surge events. 
Evidence of landform burial can be seen in the foreland of the 2004 surge, where post-1970 retreat landforms have been buried by a small debris-flow lobe emanating from the 2004 terminal moraine (Fig. 5c). This provides evidence for the modification of pre-existing glacial surge landform records by subsequent surges.

The landform assemblage observed in inner Tempelfjorden is unique in terms of three consecutive surges having modified the geomorphological record, creating a multiple surge landscape with landforms partially preserved from different surges. This has led to the construction of a more complex surging glacier landsystem model (Fig. 11) The observed landforms, however, are rather similar to those described from other Svalbard fjords where surges are known or have been inferred to occur (cf. Ottesen \& Dowdeswell, 2006; Ottesen et al. 2008; Kristensen et al. 2009). The main characteristics and glaciological significance of the submarine landforms in inner Tempelfjorden are described below.

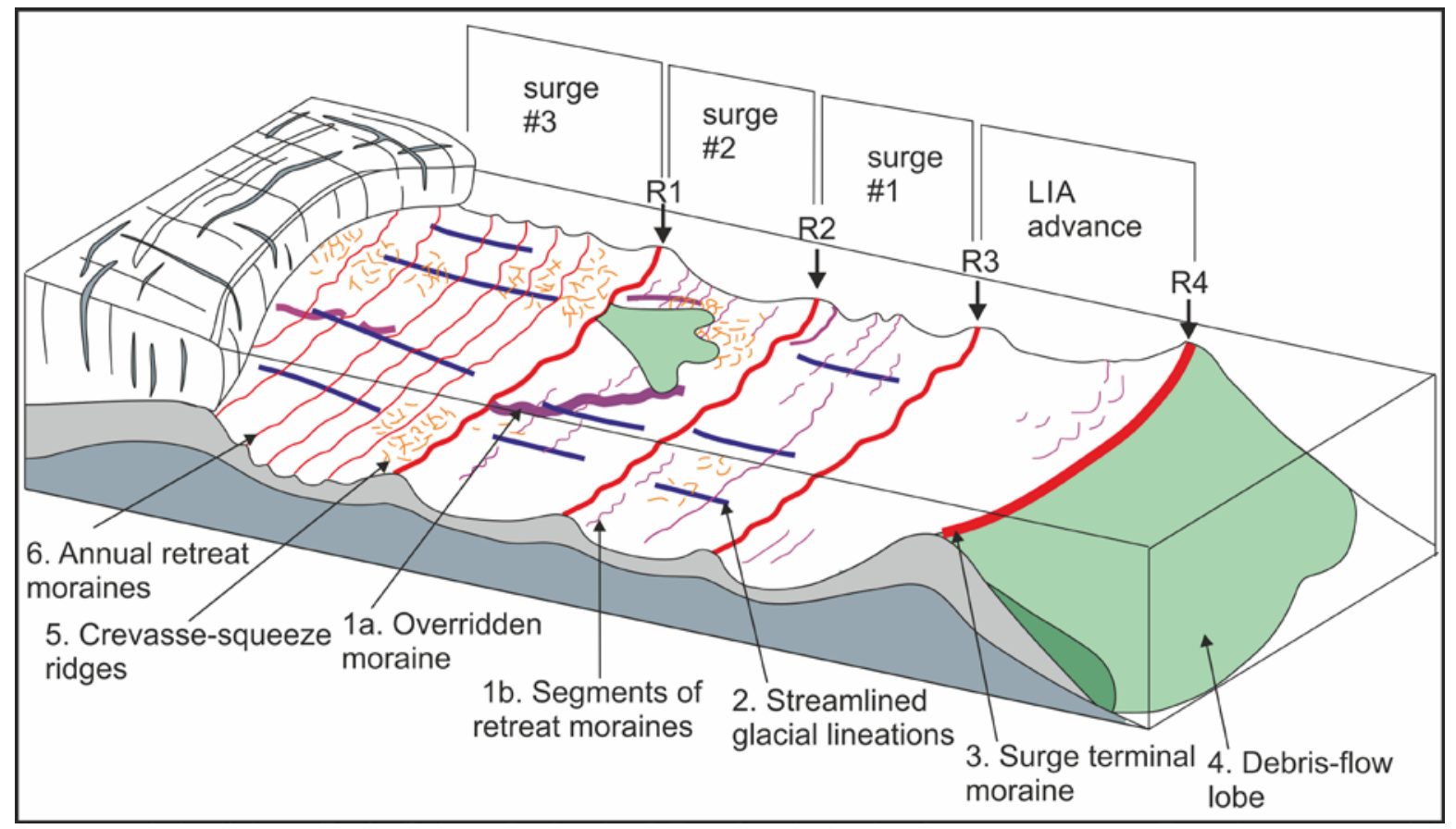

Fig.11. Multiple surge glacial landsystem model based data from Tempelfjorden.

Glacial lineations were formed during the fast ice-flow phase of each surge by molding of soft fjord-floor sediments into flow-parallel ridges and grooves. It is generally accepted that 
glacial lineations reflect fast basal ice motion (e.g. Stokes \& Clark, 2002; King et al. 2009), although it has rarely been possible to quantify either the ice velocities or the length of time required for their formation. Assuming that the lineations on the proximal side of the 2004 surge moraine were formed solely during the 2003-2005 surge, the duration and rate of terminus advance suggest that the lineations were formed during a fast-flow (with average speed of at least $1 \mathrm{~km} \mathrm{a}^{-1}$ ) phase lasting $<24$ months . However, the assumption that all lineations were generated during the 2004 surge should be taken with reservations as some of them could be inherited from earlier surges. Also, the glacier flow-velocity estimate should be considered as a minimum value because of unknown calving loss at the glacier front. This value differs somewhat from the modern ice flow-velocities in Antarctica (c. $800 \mathrm{~m} \mathrm{a}^{-1}$; Joughin et al. 2002), implying that the formation of glacial lineations in Tempelfjorden could have been relatively fast. The glacial lineations in Tempelfjorden are, however, smaller (c. 500 m long) than the several km long ones associated with LGM glaciers (Ottesen \& Dowdeswell 2009).

The terminal moraines record the location of the glacier front during successive surge maxima. The distal slope of the outermost (1870) terminal moraine is covered by lobe-shaped debris-flow deposits (Plassen et al. 2004) and numerous dislodged blocks of sediment (Fig. 4). Following Kristensen et al. (2009), we interpret the 1870 moraine and associated debrisflow deposits as evidence of bulldozing of soft fjord-floor sediments during the surge, with quasi-continuous failure of the advancing moraine front. Evidence for such a process has been observed by the authors during the recent surge of Nathorstbreen in southern Svalbard, where large mass of low shear strength fluid mud emerged in front of the glacier as it advanced along Van Keulenfjorden (Lovell, unpublished).

Commonly, large debris-flow lobes have been observed on the distal slopes of submarine surge terminal moraines in Svalbard (Ottesen et al. 2008). However, large debris-flow lobes do not 
occur in front of the inner, R1-R3 terminal moraines, even though a small debris-flow lobe is emanating from the distal slope of the 2004 surge moraine. This is uncommon in the geomorphological record of surge-type glaciers, although the same pattern (i.e. an outer ridge with debris-flow deposits and three inner ridges without debris-flow lobes) has been observed earlier in Borebukta (Ottesen \& Dowdeswell 2006). The scarceness of debris-flow deposits may reflect insufficient time for sediment accumulation due to the short surge cycle of 40 years. The sedimentation rates near the present glacier front have been estimated to $3800 \mathrm{~cm}$ $\mathrm{ka}^{-1}$ (Forwick et al. 2010). This gives an average annual sedimentation rate of $3.8 \mathrm{~cm} \mathrm{a}^{-1}$. It is likely that sedimentation rates during the active phase of the surge are much higher. However the short duration (only one to two years) of the active surge phase limits the sediment delivery to the glacier terminus leading to lower surge terminal moraines which are less likely to experience slope failure. This is demonstrated by the smaller dimensions of the R1-R3 ridges in comparison with the larger $\mathrm{R} 4$ ridge.

Networks of small ridges are widespread inside the 2004 surge limit, and locally also inside the 1970s surge moraine. The geometry and location of the networks east of the 2004 moraine, the patterns of crevasses on the glacier surface during the 2003-2005 surge (Fleming et al. 2013) (Fig. 7) and comparison with the landforms exposed by the retreating present-day ice front (Fig. 6) suggest that the networks of ridges were formed by squeezing of water-saturated basal debris into fractures, which developed in zones dominated by extensional stretching (Rea \& Evans, 2011). The surface crevasse pattern at the surge maximum in 2004 (Fig. 7) shows both, large transverse and longitudinal to oblique crevasses, indicative of fracturing due to longitudinal and transverse extension, respectively. Where crevasses are open at the bed, till can be injected to heights of up to several tens of metres aided by high basal water pressures (e.g. Fig. 6c). The crevasse-squeeze ridge pattern within the limits of the 2004 surge resembles closely that of earlier described submarine crevasse- 
squeeze ridge fields (Ottesen \& Dowdeswell. 2006, Ottesen et al. 2008). The ridge pattern within the 1970 surge limit is however distinctly different from earlier described crevassesqueeze ridge networks. We have interpreted these ridges as a combination of crevassesqueeze ridges and ice-marginal retreat moraines. Due to the relatively small dimensions of crevasse-squeeze-ridges these are easily overprinted by sediment accumulation during or following a surge event (Fig. 5c).

The transverse annual moraines are the youngest landforms in the surge landform record. They have formed by ice push during winter re-advances of the grounded glacier margin, during the post-surge retreat phase. Although the main trunk of Tunabreen has no detectable motion during the present quiescence phase, the terminal zone of the glacier undergoes longitudinal extension in response to the force imbalance at the calving front, resulting in ice velocities of up to $0.5 \mathrm{~m} \mathrm{day}^{-1}$. These velocities are sufficient to allow re-advances of a few tens of metres in the winter months, when calving rates are very small due to suppression by sea ice. The close correlation between the presence of fast sea ice (between the $25^{\text {th }}$ of February to the $27^{\text {th }}$ of June, 2013) and the period of terminal winter advance in inner Tempelfjorden implies that sea ice is an important mechanism in the formation of the annual retreat moraines (Fig. 9).

Similar retreat moraines can be observed distal to the 1970s surge moraine. The main difference between these and the post-2004 retreat moraines is that the former are not continuous across the fjord, due to later erosion and overprinting. Sections of retreat morainelike features can also be observed between the 1970-1930, as well as between the 1930-1870 surge limits. These ridge segments are incomplete and do not occur in swarms. Due to the similarities in shape and dimensions, they probably represent modified and partly overprinted retreat moraines. 
The main difference between the Tempelfjorden landsystem model (Fig. 11) and earlier submarine surge landsystem models is that multiple surges have been recorded in Tempelfjorden, leading to a modified and overprinted glacier surge landform record. The landform record produced by the 2004 surge event is similar to the landform records produced by other Svalbard surge glaciers (Ottesen et al. 2008). However a continuous set of retreat moraines can only be found proximal to the 2004 surge moraine. Debris-flow lobes are not present distal to the R2 and R3 ridges and crevasse-squeeze ridges can only be found very locally. Glacial lineations are lacking distal to the 1930s surge limit (Fig. 11).

The incomplete landform records related to the older surges can be attributed to poor preservation or burial of landforms due to the multiple surges. Sedimentation rates of $3.8 \mathrm{~cm}$ $\mathrm{a}^{-1}$ in the vicinity of the present glacier front (Forwick et al. 2010) give a sediment accumulation of around $3 \mathrm{~m}$ during 80 years. This is enough to (at least partly) bury smaller landforms, such as crevasse-squeeze ridges and retreat moraines. Overridden, partially eroded and superimposed ridge segments further indicate that the landform record has been modified. The position of the large overridden ridge between the 2004 and 1970s surge moraines (Fig.4, 11) matches the glacier terminal position in 1908, indicating that this is a modified retreat ridge. The lack of glacial lineations, crevasse-squeeze ridges and distinct retreat moraines, distal to the 1930's surge moraine suggests that the 1870 event was not a surge, but rather reflects a glacial advance due to changed climatic conditions during the LIA cold period. Terrestrial surge landsystem models differ from the Tempelfjorden model as they do not include retreat moraine ridges or debris-flow lobes. However, they do include eskers, outwash plains and hummocky moraines (Schomacker et al. 2014). The main similarity between the models is the presence of crevasse-squeeze ridges and glacial lineations. 


\section{Conclusions}

The post-Little Ice Age (LIA) dynamics of Tunabreen, a tidewater surge-type glacier in Tempelfjorden, has been reconstructed by combining published data, remote sensing (satellite images and aerial photographs) and high-resolution multibeam-bathymetric data.

The well preserved glacial landform record in the inner part of Tempelfjorden has been directly linked to the observed 2004 surge event showing with confidence that the retreat moraines have formed annually.

Ice-front positions and velocity data from feature tracking TerraSAR-X imagery has been used to correlate discrete terminal winter advances with the formation of the annual retreat moraines. The correlation between the period of the terminal winter advances and the presence of sea ice in inner Tempelfjorden suggest that sea ice is an important factor in the formation of the annual retreat ridges.

The landform record in Tempelfjorden, consisting of glacial lineations, large terminal moraines, debris-flow lobes, crevasse-squeeze ridge networks and small annual retreat moraines, shares many similarities with surge glacier landsystem models based on other Svalbard tidewater glaciers (e.g. Ottesen \& Dowdeswell, 2006; Ottesen et al. 2008). Landforms particularly characteristic of the inner Tempelfjorden include segments of retreat moraines and large overridden ridges.

The landform record in Tempelfjorden (Fig.11) is distinguished from previously proposed glacier surge landsystem models by including four sets of landform assemblages associated with the LIA advance and three subsequent surges which have partly modified the earlier 
landform records.

The landform records of the 1930s and 1970s surges are lacking debris-flow lobes suggesting that these are not an integral part of a glacier surge landsystem model. The presence of debrisflow lobes is most likely related to the length of the active surge phase.

The landform record of the von Postbreen LIA advance differs from the surge landform record by lacking glacial lineations, crevasse-squeeze ridges and distinct retreat moraines. This might be due to poor preservation of the landform record. Alternatively, the von Postbreen advance was not a surge-related process but rather a climatically controlled one.

\section{Acknowledgements}

Permission for presenting the bathymetric data was granted by the Norwegian Hydrographic Service (permission nr. 13/G706). Landsat satellite images were acquired from USGS Earth Explorer and the Global Land Cover Facility. ASTER satellite images were acquired from the NASA Land Processes Distributed Active Archive Center (LPDAAC). Envisat data were provided by ESA through project AOCRY2676. TerraSAR-X data were provided by DLR through project OCE1503, and funded by the ConocoPhillips-Lundin Northern Area Program project CRIOS (Calving Rates and Impact on Sea Level). The topographic maps and aerial photographs were obtained from the Norwegian Polar Institute (NPI). Aerial photos were provided by NERC Earth Observation Data Centre. H. Lovell was funded by a NERC PhD studentship (NE/I528050/1), the Queen Mary Postgraduate Research Fund and the Arctic Field Grant program of the Research Council of Norway. UNIS logistics is thanked for fieldwork support. Parts of this work benefitted from discussions with Ed Fleming and Sven Lukas, and we would also like to thank Sarah Greenwood at Stockholm University as well as 
Teena Chauhan, Srikumar Roy and Oscar Fransner from UNIS for commenting on the early draft. We would also like to thank Henry Patton and an anonymous reviewer for providing valuable feedback on the manuscript.

\section{References}

Benediktsson., Schomacker A., Lokrantz H., Ingolfsson.O. 2010. The 1890 surge end moraine at Eyjabakkajokull, Iceland: a re-assessment of a classic glaciotectonic locality. Quaternary Science Reviews Vol. 29. 484- 506.

Bennett M., Hambrey M. J., Huddart D., Ghienne J. F. 1996. The formation of a geometrical ridge network by the surge-type glacier Kongsvegen, Svalbard. Journal of Quaternary Science. Vol. 11. No. 6: 437-449.

Boulton G.S., Van Der Meer J.J. M., Hart J., Beets D., Ruegg. G. H.J., Van Der Wateren. F. M, Jarvis. J. 1996. Till and moraine emplacement in a deforming bed surge-An example from a marine environment. Quaternary Science Reviews . Vol.15. 961-987.

Brynjólfsson S., Ingólfsson Ó., Schomacker A. 2012. Surge fingerprinting of cirque glaciers at the Tröllaskagi peninsula, North Iceland. Jökull. Vol. 62. 151-166.

De Geer G. 1910. Guide de l`excursion au Spitsberg. Excursion A1. (Guide to excursions on Spitsbergen A1.) Stockholm: XI International Geological Congress.

Dowdeswell J. A., Hamilton G. S. \& Hagen J. O. 1991. The duration of the active phase on 
surge-type glaciers: contrasts between Svalbard and other regions. Journal of glaciology. Vol. 37. No. $127.388-400$.

Evans D. J. A., Rea B. R. 1999. Geomorphology and sedimentology of surging glaciers: a landsystem approach. Annals of Glaciology. Vol. 28. 75-82

Evans D. J. A., Rea B. R. 2003. Surging glacial landsystems in: Evans. D. J. A (Ed). Glacial Landsystems. Arnold, London. 259-288.

Fleming E., Lovell H., Stevenson C., Petronis M., Benn D.I., Hambrey M., Fairchild I. 2013. Magnetic fabrics in basal ice of a surge-type glacier. Journal of Geophysical Research. Vol. 118. 2263-2278.

Forwick M. \& Vorren T. O. 2009. Late Weichselian and Holocene sedimentary environments in Isfjorden, Spitsbergen. Palaeogeography, Palaeoclimatology, Palaeoecology. Vol. 280. $258-274$.

Forwick M., Vorren T. O., Hald M., Korsun S., Roh Y., Vogt C., Yoo K-C. 2010. Spatial and temporal influence of glaciers and rivers on: the sedimentary environment in Sassenfjorden and Tempelfjorden, Spitsbergen. Geological society of London, Special publications. Vol.44. 163-183.

Fowler A.C., Murray T., Ng F. 2001. Thermally controlled glacier surging. Journal of Glaciology. Vol. 47. 527-538. 
Joughin I., Tulaczyk L., Bindschadler R., Price S. F., 2002. Changes in west Antarctic ice stream velocities: Observations and analysis. Journal of geophysical research. Vol. 107

Hagen J. O., Liestol O., Roland E., Jorgensen T. 1993. Glacier Atlas of Svalbard and Jan Mayen Norwegian Polar Institute. Meddelelser. No. 129. 1-169

Hodgkins R., Dowdeswell J.A. 1994. Tectonic processes in Svalbard tide-water glacier surges: evidence from structural glaciology. Journal of Glaciology. Vol. 40. No. 136. 553560.

King E.C., Hindmarsh R.C.A., Stokes C.R. 2009. Formation of mega-scale glacial lineations observed beneath a West Antarctic ice stream. Nature Geoscience. Vol. 2. 585-588.

Kristensen L., Benn D.I. 2012. A surge of Skobreen/Paulabreen, Svalbard, observed by timelapse photographs and remote sensing data. Polar Research Vol. 31. 1-9.

Kristensen L., Benn D.I., Hormes A., Ottesen D. 2009. Mud aprons in front of Svalbard surge moraines: evidence of subglacial deforming layers or proglacial tectonics? Geomorphology. Vol. 111 (3-4), 206-221.

Lawson W.J., Sharp M.J., Hambrey M.J., 2000. Deformation histories and structural assemblages of glacier ice in a non-steady flow regime. In: Maltman, A.J., Hubbard, B. and Hambrey, M.J. (eds.) Deformation of Glacial Materials. Geological Society, London, Special 
Publication. 176, 55-96.

Liestøl O. 1969. Glacier surges in West Spitsbergen. Canadian Journal of Earth Sciences. Vol. 6. 895-897.

Lovell H., Fleming E.J., Benn D.I., Hubbard B., Lukas S., Flink A.E., Noormets R. In prep. Debris entrainment during tidewater glacier surges and implications for landform genesis at Tunabreen, Svalbard.

Mangerud J., Bolstad M., Elgersma A., Helliksem D., Landvik J. Y., Lonne I., Lycke A. K.,Salvigsen O., Sandahl T., Svendsen J. I. 1992. The last glacial maximum on Spitsbergen, Svalbard. Quaternary Research. Vol. 28. 1-31.

Mansell D., Luckman A., Murray T. 2012. Dynamics of tidewater surge-type glaciers in northwest Svalbard. Journal of Glaciology. Vol. 58. No. 207. 110-118.

Marchenko A. V., Morozov E.G., Muzylev S. V. 2012. A tsunami wave recorded near a glacier front. Natural Hazards and Earth System Science. Vol. 12. 415-419.

Meier M. F., Post A.S. 1969. What are glacier surges? Canadian Journal of Earth Sciences. Vol. 6. 807-819.

Murray T., Strozzi T., Luckman A., Jiskoot, H., Christakos P. 2003. Is there a single surge mechanism? Contrasts in dynamics between glacier surges in Svalbard and other regions. 
Journal of Geophysical Research. Vol. 108. No. B5. 1-15.

Ottesen D., Dowdeswell J.A. 2006. Assemblages of submarine landforms produced by tidewater glaciers in Svalbard: Journal of Geophysical Research, Earth Surface. Vol. 111.116.

Ottesen D., Dowdeswell J. A., Benn D. I., Kristensen L., Christiansen H. H., Christensen O., Hansen L., Lebesbye E., Forwick M., Vorren T. O. 2008. Submarine landforms characteristic of glacier surges in two Spitsbergen fjords: Quaternary Science Reviews. Vol. 27, No. 1516.1583-1599.

Ottesen D., Dowdeswell J. A. 2009. An inter-ice-stream glaciated margin: Submarine landforms and a geomorphic model based on marine-geophysical data from Svalbard. Geological Society of America Bulletin. Vol.121. No. 11-12. 1647-1665

Plassen L., Vorren T. O., Forwick M. 2004. Integrated acoustic and coring investigation of glacigenic deposits in Spitsbergen fjords. Polar Research. Vol. 23. 89-110.

Rea B., Evans D.J.A. 2011. An assessment of surge-induced crevassing and the formation of crevasse-squeeze ridges. Journal of Geophysical Research, Earth Surface. DOI: 10.1029/2011JF001970

Schomacker A., Benediktsson O. I., Ingolfsson O. 2014. The Eyjabakkajökull glacial landsystem, Iceland: Geomorphic impact of multiple surges. Geomorphology. Vol. 218. 98- 
Solheim A. 1991. The depositional environment of surging sub-polar tidewater glaciers. Norsk polarinstitutt skrifter, (Norwegian polarinstitute) No. 194. 1-97.

Stokes C., Clark C.D. 2002. Are long subglacial bedforms indicative of fast ice flow? Boreas. Vol. 31. 239-249.

Svendsen J. I., Elverhoi A., Mangerud J. 1996. The retreat of the Barents Sea ice sheet on the western margin. Boreas. Vol. 25. 244-256.

Svendsen, J.I., Mangerud, J., 1992. Paleoclimatic inferences from glacial fluctuations on Svalbard during the last 2000 years. Climate Dynamics 6, 213-220. 